\title{
Effects of vermicompost on growth and leaf biomass yield of stevia and post harvest fertility status of soil
}

\author{
M. M. Zaman, M. A. H. Chowdhury ${ }^{1^{*}}$, M. R. Islam² and M. R. Uddin ${ }^{3}$ \\ Soil Resource Development Institute, Farmgate, Dhaka, ${ }^{1 \& 3}$ Department of Agricultural Chemistry and Department of \\ Agronomy, Bangladesh Agricultural University, Mymensingh-2202 and ${ }^{2}$ School of Agriculture and Rural Development, \\ Bangladesh Open University, Gazipur, Bangladesh, *E-mail: akhterbau11@gmail.com
}

\begin{abstract}
In view of the growing awareness about eco-friendly organic farming, vermicompost (VC) could be a very good option for increasing crops yield. The organic carbon in VC releases nutrients slowly and steadily into the system and enables the plant to absorb these nutrients. To assess the effect of VC on soil fertility, growth and yield of stevia in acid and non-calcareous soils, an experiment was undertaken in the net house of the Department of Agricultural Chemistry, Bangladesh Agricultural University, Mymensingh, during February to May, 2012. Four levels of VC viz. 0, 5, 7.5 and $10 \mathrm{t} \mathrm{ha}^{-1}$ in two contrasting soils (Acid and Non-calcareous) were examined following CRD with three replications. Growth and yield attributes such as plant height, branch and leaf number, leaf area, fresh and dry weight of leaves were significantly influenced by different levels of VC. All the plant parameters increased with the advancement of growth period as well with increased rate of VC up to $7.5 \mathrm{t} \mathrm{ha}^{-1}$ and then declined with further additions. The leaf biomass yield was 335\% and 338\% higher in acid soil and in non-calcareous soil, respectively over control. The overall performance of noncalcareous soil was superior to acid soil in terms of both plant and soil parameters studied. The acidity of both soils significantly decreased with the increased application of VC ranging from 4.9 to 5.7 in acid soil and 6.5 to 7.2 in noncalcareous soil. Total $\mathrm{N}$, available $\mathrm{P}$, exchangeable $\mathrm{K}, \mathrm{Ca}, \mathrm{Mg}$, available $\mathrm{S}, \mathrm{Zn}, \mathrm{B}$ were also significantly increased with the increased levels of VC up to its highest level (VC @ 10t ha ${ }^{-1}$ ) in both soils. Thus the results suggest that VC @ 7.5t ha ${ }^{-1}$ should be applied for getting maximum leaf biomass yield of stevia and $10 \mathrm{t} \mathrm{ha}^{-1}$ for increasing the fertility of both soils under the agro-climatic conditions of the studied area.
\end{abstract}

Keywords: Stevia, Vermicompost, Leaf biomass yield, Soil fertility

\section{Introduction}

Stevia, approximately 100 to 300 times sweeter than table sugar, has numerous health benefits (Barathi, 2003). It gives a feeling of even energy, rather than the ups and downs created with white sugar (Sunrider, 2007). Stevia leaf is calorie-free and non-disruptive to blood sugar levels. So far, there have been no recorded side effects from stevia consumption (Wort, 2013). In Bangladesh, about 8 millions of people between 20 to 69 years have been suffering from this serious disease which is about $5.9 \%$ of the total population and increasing at an alarming pace. Most dangerous message is huge numbers of children aged from 8 to 20 years old have also been suffering from this serious disease (Genus,, 2004). It is a new avenue to do research for the researcher and is a good opportunity for the farmers to earn cash money through cultivation of stevia. Though it is a perennial crop, leaves can be harvested 3 to 4 times in a year. The stevia cultivation has an immense scope for intensive agriculture and fits well for high return agriculture (Barathi, 2003). In view of the above fact, cultivation of stevia is gradually coming into focus in Bangladesh agriculture due to having no optimum agronomic management practices (Khanom, 2007, Nasrin, 2008 and Hasan, 2008). Few experiments were conducted on different agronomic aspects like date of planting, pruning, stem cutting etc on the growth and yield of stevia (Khan, 2014). It is expected that a higher and balanced nutrient supply will result in higher foliage yield. One of the best organic materials for increasing crop yield is vermicompost. In view of the growing awareness about eco-friendly organic farming, it showed growth promoting effect on the crops. Vermicomposting involves the bio-oxidation and stabilization of organic material by the joint action of earthworms and microorganisms. Earthworms act as mechanical blenders and by comminuting the organic matter they modify its physical and chemical status by gradually reducing the $\mathrm{C}$ : $\mathrm{N}$ ratio and increasing the surface area exposed to microorganisms thus making it much more favourable for microbial activity and further decomposition (Domínguez et al., 1997). 
During the process, important nutrients are released by earthworms (Edwards, 1995). Vermicompost contains plant growth hormones (Arancon and Edwards, 2006), growth regulating substances and humic acids (Atiyeh et al., 2002) which enhance plant growth and productivity (Sahni et al., 2008). Vermicompost being a stable fine granular organic matter, when added loosens the soil and improves the passage for the entry of air. The mucus associated with the cast being hydroscopic absorbs water and prevents water logging and improves water-holding capacity. The organic carbon in vermicompost releases the nutrients slowly and steadily into the system and enables the plant to absorb these nutrients. The soil enriched with vermicompost provides additional substances that are not found in chemical fertilizers (Kale, 1998). Along with the chemical fertilizers organic manures can be mixed to the soil to control nutrient deficiency, increase organic matter content, water holding capacity of the soil to stimulate the activity of beneficial microorganisms that makes the plant food elements in the soil readily available to the plants. The existing situation demands the need for research to study the fertilizer recommendation for cultivation of stevia plant in Bangladesh maintaining soil health using eco-friendly organic material like vermicompost. The current aim of the study was to examine the influence of vermicompost application on the growth, leaf yield of stevia and to investigate the fertility status of post harvest soil.

\section{Materials and Methods}

The experiment was carried out with stevia plant in the Department of Agricultural Chemistry, BAU, Mymensingh during February to May, 2012. The research works were accomplished in 24 earthen pots in a completely randomized design with three replications. The soil was mixed thoroughly with vermicompost (VC) as per treatments $\left\{\mathrm{VC}_{0}\right.$ (control), $\mathrm{VC}_{5}\left(5 \mathrm{t} \mathrm{ha}^{-1}\right), \mathrm{VC}_{7.5}\left(7.5 \mathrm{t} \mathrm{ha}^{-1}\right)$ and $\left.\mathrm{VC}_{10}\left(10 \mathrm{t} \mathrm{ha}{ }^{-1}\right)\right\}$. The $\mathrm{VC}$ contained 8.93, $1.35,0.81,0.62,0.28,0.15$ and $0.016 \%$ organic $\mathrm{C}$, total $\mathrm{N}, \mathrm{P}, \mathrm{K}, \mathrm{S}, \mathrm{Ca}$ and $\mathrm{Mg}$, respectively. Eight $\mathrm{kg}$ of processed soil was taken in each earthen pot.

Forty five day old in vitro produced stevia seedlings were collected from brac Biotechnology Laboratory, Joydebpur, Gazipur to use in the experiment. Two soils (Acid and non-calcareous) of contrasting physicochemical properties (Zaman et al, 2015) collected from Madhupur (Tangail) and BAU campus (Mymensingh), respectively were used. For the initial growth and development of the seedling, small amounts of urea (appx.1g) were applied to each pot including control. Intercultural operations like irrigation, soil loosening, weeding, plant protection and deflowering were done as and when necessary. Harvesting, cleaning, drying and weighing were done properly.

Plant height, branches plant ${ }^{-1}$, leaves plant ${ }^{-1}$, leaf area plant ${ }^{-1}$, fresh leaf weight, dry leaf weight were studied at 15, 30,45 and 60 days after planting (DAP). Initial and post-harvest soil properties were determined following standard methods (Page et al., 1982) in the Laboratories of the Departments of Agricultural Chemistry, Biochemistry, Professor Muhammed Hussain Central Laboratory (PMHCL), BAU, Mymensingh and SRDI Regional Laboratory, Dhaka. Analysis of variance (ANOVA) was done following the principle of F-statistics and the mean values were separated by Duncan's Multiple Range Test (Gomez and Gomez, 1984).

\section{Results and Discussion}

\section{Plant height}

The mean data on plant height as influenced by different levels of VC have been presented in Table 1 . The data revealed that $\mathrm{VC}$ application significantly affected the height of stevia plant irrespective of growth period and soils used.

VC @ $7.5 \mathrm{t} \mathrm{ha}^{-1}$ recorded the highest plant height of $105 \mathrm{~cm}$ in acid soil and $98 \mathrm{~cm}$ in the non-calcareous soil at 60 DAP which was identical with $\mathrm{VC}_{10}$ and the lowest plant height was observed from control. $\mathrm{VC}$ application at all levels increased plant height by 20 to $41 \mathrm{~cm}$ in acid soil and 23 to $36 \mathrm{~cm}$ in non-calcareous soil, respectively at harvest. Plant height was also significantly increased with the advancement of the growth period irrespective of VC levels. Plant height was $65 \%$ higher in acid soil and $58 \%$ in non-calcareous soil over control. The result was identical with Kumar et al. (2011) and Shadanpour et. al. (2011) who found that application of vermicompost increased the plant height in stevia and marigold, respectively. 
Table 1. Effects of different levels of vermicompost on the plant height of stevia at various DAP*

\begin{tabular}{|c|c|c|c|c|c|c|c|c|c|c|}
\hline \multirow{3}{*}{ VC level } & \multicolumn{10}{|c|}{ Plant height (cm) } \\
\hline & \multicolumn{5}{|c|}{ Acid soil } & \multicolumn{5}{|c|}{ Non-calcareous soil } \\
\hline & 0 & 15 & 30 & 45 & 60 & 0 & 15 & 30 & 45 & 60 \\
\hline$\overline{\mathrm{VC}_{0}}$ & 11.0 & $18.3 c$ & $44.0 \mathrm{~b}$ & $50.0 \mathrm{c}$ & $64.0 d$ & 13.0 & $20.0 b$ & $40.0 \mathrm{~b}$ & $43.0 d$ & $61.7 \mathrm{c}$ \\
\hline $\mathrm{VC}_{5}$ & 12.0 & $20.0 c$ & $47.0 \mathrm{~b}$ & $59.7 b$ & $84.0 \mathrm{c}$ & 13.3 & $21.7 b$ & $51.3 a$ & $60.3 c$ & $85.0 \mathrm{~b}$ \\
\hline $\mathrm{VC}_{7.5}$ & 13.3 & $26.0 a$ & $58.3 a$ & $82.0 a$ & $105.3 a$ & 15.0 & $25.3 a$ & $56.3 a$ & $73.3 a$ & $97.7 \mathrm{a}$ \\
\hline $\mathrm{VC}_{10}$ & 11.3 & $22.7 \mathrm{~b}$ & $53.0 \mathrm{a}$ & $77.0 \mathrm{a}$ & $93.7 b$ & 14.0 & $24.3 a$ & $52.3 a$ & $66.7 \mathrm{~b}$ & $89.0 b$ \\
\hline$\overline{\mathrm{CV}}(\%)$ & 1.4 & 1.6 & 1.4 & 2.1 & 1.9 & 1.3 & 1.3 & 1.5 & 2.0 & 1.8 \\
\hline $\mathrm{LSD}_{0.65}$ & 1.9 & 2.6 & 5.3 & 7.0 & 9.1 & 2.1 & 2.8 & 5.2 & 6.2 & 8.0 \\
\hline
\end{tabular}

*DAP $=$ Days after planting, $C V=$ Coefficient of variance, LSD $=$ Least significant difference

\section{Branch number}

Branch number plant ${ }^{-1}$ was significantly affected by the addition of VC in both soils (Table 2). The result revealed that branches plant ${ }^{-1}$ progressively increased with increasing levels of VC up to $7.5 \mathrm{t} \mathrm{ha}^{-1}$ in both soils and then declined with further addition.

Table 2. Effects of different levels of vermicompost on the branch number of stevia at various DAP*

\begin{tabular}{|c|c|c|c|c|c|c|c|c|c|c|}
\hline \multirow{3}{*}{ VC level } & \multicolumn{10}{|c|}{ Branches Plant $^{-1}$ (No.) } \\
\hline & \multicolumn{5}{|c|}{ Acid soil } & \multicolumn{5}{|c|}{ Non-calcareous soil } \\
\hline & 0 & 15 & 30 & 45 & 60 & 0 & 15 & 30 & 45 & 60 \\
\hline $\mathrm{VC}_{0}$ & 1.0 & $1.3 b$ & $1.7 \mathrm{~b}$ & $1.7 \mathrm{~b}$ & $2.0 \mathrm{c}$ & 1.0 & $1.3 b$ & $1.3 b$ & $1.7 \mathrm{~b}$ & $2.0 \mathrm{c}$ \\
\hline $\mathrm{VC}_{5}$ & 1.0 & $1.7 \mathrm{a}$ & $2.0 \mathrm{~b}$ & $2.3 b$ & $3.3 b$ & 1.0 & $1.7 \mathrm{a}$ & $2.0 \mathrm{a}$ & $2.3 b$ & $3.3 a b$ \\
\hline $\mathrm{VC}_{7.5}$ & 1.0 & $2.3 a$ & $3.3 a$ & $3.7 a$ & $4.7 \mathrm{a}$ & 1.0 & $2.3 a$ & $2.7 \mathrm{a}$ & $3.3 a$ & $4.7 a$ \\
\hline $\mathrm{VC}_{10}$ & 1.0 & $2.0 \mathrm{a}$ & $2.3 b$ & $3.3 a$ & $4.3 a$ & 1.0 & $2.0 \mathrm{a}$ & $2.3 a$ & $3.0 \mathrm{a}$ & $3.7 \mathrm{a}$ \\
\hline $\mathrm{CV}(\%)$ & 0.0 & 3.8 & 3.7 & 3.7 & 3.5 & 0.0 & 3.8 & 3.7 & 3.4 & 3.7 \\
\hline $\mathrm{LSD}_{0.05}$ & 0.0 & 0.8 & 0.8 & 0.8 & 0.9 & 0.0 & 0.8 & 0.8 & 0.8 & 1.1 \\
\hline
\end{tabular}

*DAP $=$ Days after planting, CV = Coefficient of variance, $L S D=$ Least significant difference

VC application influenced branch numbers variably from 15 to 60 DAP irrespective of soils. The highest number of branches plant ${ }^{-1}$ was obtained from the plant receiving $7.5 \mathrm{tVC}^{-1}$ hat harvest which was significantly different from other treatments in non-calcareous soil whereas identical results on branch number were observed with all the VC levels except control in acid soil. The lowest branch number was counted from the plant grown in control pot. VC application at all levels increased branch number by 65$135 \%$ in both acid and non-calcareous soil at harvest. Kumar et al. (2011) studied with stevia showed that application of organic manures instead of chemical fertilizers using vermicompost resulted in significantly maximum number of branches plant ${ }^{-1}$.

\section{Leaf number}

The data revealed that the number of leaves plant ${ }^{-1}$ was significantly influenced by different levels of VC in both acid and non-calcareous soils at all growth stages except 0 DAP (Table 3). Leaf number was increased with the increased levels of $\mathrm{VC}$ up to $7.5 \mathrm{t} \mathrm{ha}^{-1}$ and then declined with further addition $\left(\mathrm{VC}_{10}\right)$ by $43 \%$ and $35 \%$ in acid soil and non-calcareous soil, respectively.

Table 3. Effects of different levels of vermicompost on the leaf number of stevia at various DAP*

\begin{tabular}{|c|c|c|c|c|c|c|c|c|c|c|}
\hline \multirow{3}{*}{ VC level } & \multicolumn{10}{|c|}{ Leaves Plant $^{-1}$ (No.) } \\
\hline & \multicolumn{5}{|c|}{ Acid soil } & \multicolumn{5}{|c|}{ Non calcareous soil } \\
\hline & 0 & 15 & 30 & 45 & 60 & 0 & 15 & 30 & 45 & 60 \\
\hline $\mathrm{VC}_{0}$ & 6.0 & $9.0 \mathrm{c}$ & $18.0 d$ & $27.3 d$ & $42.3 c$ & 6.0 & $14.0 d$ & $21.3 d$ & $29.7 d$ & $44.7 d$ \\
\hline $\mathrm{VC}_{5}$ & 6.0 & $12.0 \mathrm{c}$ & $25.0 \mathrm{c}$ & $49.0 \mathrm{c}$ & $92.0 \mathrm{~b}$ & 6.0 & $23.0 \mathrm{c}$ & $35.7 \mathrm{c}$ & $55.3 c$ & $97.0 \mathrm{c}$ \\
\hline $\mathrm{VC}_{7.5}$ & 7.3 & $47.3 a$ & $67.3 a$ & $95.0 \mathrm{a}$ & $181.0 \mathrm{a}$ & 6.3 & $34.0 \mathrm{a}$ & $56.0 \mathrm{a}$ & $114.0 \mathrm{a}$ & $196.7 a$ \\
\hline $\mathrm{VC}_{10}$ & 8.0 & $36.7 \mathrm{~b}$ & $43.7 b$ & $82.0 \mathrm{~b}$ & $103.0 b$ & 6.0 & $28.3 b$ & $47.3 b$ & $80.7 b$ & $128.0 b$ \\
\hline $\mathrm{CV}(\%)$ & 3.5 & 6.3 & 5.1 & 4.3 & 4.9 & 2.9 & 3.1 & 3.4 & 4.6 & 4.8 \\
\hline LSD $_{0.05}$ & 2.3 & 3.1 & 4.3 & 7.5 & 12.1 & 2.3 & 2.5 & 4.4 & 8.1 & 13.4 \\
\hline
\end{tabular}

${ }^{*} \mathrm{DAP}=$ Days after planting, $\mathrm{CV}=$ Coefficient of variance, $\mathrm{LSD}=$ Least significant difference 
The increasing trend of number of leaf was slower at the early growth stages (0-30 DAP) while it was rapid between 30 and 60 DAP irrespective of VC levels except control. VC application at all levels increased the number of leaves by 50 to 139 in acid soil and 53 to 152 in non-calcareous soil, respectively. Maximum number of leaves was recorded with $\mathrm{VC}_{7.5}$ which was significantly higher than all other levels of $\mathrm{VC}$ in both soils. Plants fertilized with $\mathrm{VC}_{5}$ and $\mathrm{VC}_{10}$ produced identical number of leaves in acid soil. The minimum number of leaves plant ${ }^{-1}$ was harvested from the plants fertilized with no VC irrespective of soils and growth period. The application of organic manures like vermicompost instead of chemical fertilizers resulted in significantly maximum number of leaves of stevia plant (Kumar et. al., 2011).

\section{Leaf area}

Total leaf area plant ${ }^{-1}$ at harvest as influenced by different levels of VC has been presented in Table 4. Leaf area plant ${ }^{-1}$ responded significantly due to the application of different levels of VC. The result revealed that leaf area progressively increased with increasing levels of $\mathrm{VC}$ application up to $7.5 \mathrm{tha}^{-1}$ in both soils and then declined with further addition $\left(V C_{10}\right)$. The highest total leaf area plant ${ }^{-1}\left(1126 \mathrm{~cm}^{2}\right.$ in acid soil and $1480 \mathrm{~cm}^{2}$ in non-calcareous soil) at harvest was measured from the plant receiving $7.5 \mathrm{t}$ VC $\mathrm{ha}^{-1}$ which was significantly higher than other levels. The lowest leaf area was found from the control treatment irrespective of soils used. At harvest, VC application at all levels increased leaf area by 142$402 \%$ in acid soil and 175 to $464 \%$ in non-calcareous soil, respectively. Kumar et. al. (2011) found that the application of organic manures like vermicompost instead of chemical fertilizers resulted in significantly maximum leaf area of stevia plant.

\section{Dry weight}

The dry weight of stevia leaves plant ${ }^{-1}$ at harvest varied significantly due to the application of different levels of VC (Table 4).

Table 4. Effects of different levels of vermicompost on leaf area, dry weight and yield increase of stevia leaves over control at harvest

\begin{tabular}{l|cc|c|c|c|c}
\hline \multirow{3}{*}{$\mathrm{VC}$ level } & \multicolumn{2}{|c|}{$\begin{array}{c}\text { Leaf area plant } \\
\left(\mathrm{cm}^{-1}\right)\end{array}$} & \multicolumn{2}{c|}{$\begin{array}{c}\text { Leaf dry weight } \\
\left(\mathrm{g} \mathrm{plant}^{-1}\right)\end{array}$} & $\begin{array}{c}\text { Yield increase } \\
\text { over control (\%) }\end{array}$ & $\begin{array}{c}\text { Yield increase } \\
\text { over control (\%) }\end{array}$ \\
\cline { 2 - 8 } & $\begin{array}{c}\text { Acid } \\
\text { soil }\end{array}$ & $\begin{array}{c}\text { Non- } \\
\text { calcareous soil }\end{array}$ & $\begin{array}{c}\text { Acid } \\
\text { soil }\end{array}$ & $\begin{array}{c}\text { Non- } \\
\text { calcareous soil }\end{array}$ & $\begin{array}{c}\text { Acid } \\
\text { soil }\end{array}$ & $\begin{array}{c}\text { Non-calcareous } \\
\text { soil }\end{array}$ \\
\hline $\mathrm{VC}_{0}$ & $224 \mathrm{~d}$ & $262 \mathrm{c}$ & $1.35 \mathrm{~d}$ & $1.45 \mathrm{~d}$ & - & - \\
$\mathrm{VC}_{5}$ & $544 \mathrm{c}$ & $721 \mathrm{bc}$ & $2.98 \mathrm{c}$ & $3.11 \mathrm{c}$ & 119 & 114 \\
$\mathrm{VC}_{7.5}$ & $1126 \mathrm{a}$ & $1480 \mathrm{a}$ & $5.95 \mathrm{a}$ & $6.35 \mathrm{a}$ & 335 & 338 \\
$\mathrm{VC}_{10}$ & $797 \mathrm{~b}$ & $1032 \mathrm{~b}$ & $3.42 \mathrm{~b}$ & $4.20 \mathrm{~b}$ & 151 & 190 \\
\hline $\mathrm{CV}(\%)$ & 4 & 5 & 4.91 & 4.82 & - & - \\
$\mathrm{LSD}_{0.05}$ & 157 & 413 & 0.41 & 0.45 & - & - \\
\hline
\end{tabular}

$\mathrm{CV}=$ Coefficient of variance, $\mathrm{LSD}=$ Least significant difference

Dry weight gradually increased with increasing levels of VC application up to $7.5 \mathrm{t} \mathrm{ha}^{-1}$ in both soils and then declined with further addition $\left(\mathrm{VC}_{10}\right)$. The highest dry weight plant ${ }^{-1}(5.95 \mathrm{~g}$ in acid soil and $6.35 \mathrm{~g}$ in non-calcareous soil) at harvest was obtained from the plant fertilized with $7.5 \mathrm{t} \mathrm{VC} \mathrm{ha}^{-1}$ which was significantly higher than other levels. The lowest values were obtained from the control treatment $(1.35 \mathrm{~g}$ in acid soil and $1.45 \mathrm{~g}$ in non-calcareous soil). VC application at all levels increased leaf dry yield at harvest by 119 to $335 \%$ in acid soil and 114 to 338\% in non-calcareous soil, respectively over control. Azarpour et al., (2013) showed that vermicompost had a significant positive effect on dry weight of stevia as compared with the plant grown in soil without vermicompost. They obtained highest fresh leaf biomass yield of stevia from the treatment where10t ha ${ }^{-1}$ vermicompost were applied. 


\section{Post-harvest fertility status of soil}

Results on the chemical properties of post harvest soils as influenced by different levels of VC are presented in Table ( $5 \mathrm{a}$ and $5 \mathrm{~b}$ ). The data revealed that all the parameters were significantly influenced by the addition of VC irrespective of soils used.

Table 5a. Effects of different levels of vermicompost on the fertility of post harvest soils

\begin{tabular}{|c|c|c|c|c|c|c|c|c|c|c|}
\hline \multirow[t]{2}{*}{ Levels of VC } & \multicolumn{2}{|c|}{$\mathrm{pH}$} & \multicolumn{2}{|c|}{ Organic matter (\%) } & \multicolumn{2}{|c|}{$\begin{array}{l}\text { Total N } \\
\left(\mu \mathrm{g} \mathrm{g}^{-1}\right)\end{array}$} & \multicolumn{2}{|c|}{$\begin{array}{c}\text { Available P } \\
\left(\mu \mathrm{g} \mathrm{g}^{-1}\right)\end{array}$} & \multicolumn{2}{|c|}{$\begin{array}{c}\text { Exch. K } \\
\left(\mathrm{cmol} \mathrm{kg}^{-1}\right)\end{array}$} \\
\hline & AS & NS & AS & NS & AS & NS & AS & NS & AS & NS \\
\hline $\mathrm{VC}_{0}$ & 4.9 & 6.5 & $1.70 \mathrm{~d}$ & $1.28 d$ & $0.10 \mathrm{~b}$ & $0.12 b$ & $2.83 d$ & $10.00 d$ & $0.18 a b$ & $0.15 b$ \\
\hline $\mathrm{VC}_{5}$ & 5.2 & 6.7 & $1.89 \mathrm{c}$ & $1.71 \mathrm{c}$ & $0.15 a b$ & $0.18 a b$ & $4.47 \mathrm{c}$ & $14.08 \mathrm{c}$ & $0.23 a$ & $0.19 a b$ \\
\hline $\mathrm{VC}_{7.5}$ & 5.4 & 7.0 & $2.13 b$ & $2.19 b$ & $0.21 a$ & $0.22 a$ & $7.30 \mathrm{~b}$ & 17.10b & $0.27 a$ & $0.24 a$ \\
\hline $\mathrm{VC}_{10}$ & 5.7 & 7.2 & $2.39 a$ & $2.61 a$ & $0.25 a$ & $0.25 a$ & $8.64 a$ & $20.26 a$ & $0.29 a$ & $0.31 \mathrm{a}$ \\
\hline $\mathrm{CV}(\%)$ & 4.2 & 4.1 & 3.10 & 5.40 & 8.12 & 7.30 & 9.40 & 4.85 & 5.30 & 5.31 \\
\hline $\mathrm{LSD}_{0.05}$ & 0.08 & 0.09 & 0.09 & 1.00 & 0.07 & 0.09 & 0.72 & 2.96 & 0.09 & 0.08 \\
\hline
\end{tabular}

AS = Acid soil, NS = Non-calcareous soil, CV = Coefficient of variance, $L S D=$ Least significant difference, Exch.= Exchangeable

The values of the soil parameters were increased with the increased levels of VC. The acidity of both soils decreased with the application of $\mathrm{VC}(\mathrm{pH}$ ranged from 4.9 to 5.7 in acid soil and 6.5 to 7.2 in non-calcareous soil). Organic matter content of both soils increased significantly over control and ranged from 1.7 to $2.39 \%$ in acid soil but 1.28 to $2.61 \%$ in non-calcareous soil. The contents of total $\mathrm{N}$, available $\mathrm{P}$, exchangeable $\mathrm{K}, \mathrm{Ca}$, $\mathrm{Mg}$, available S, Zn, B were also significantly increased with the increased levels of $\mathrm{VC}$ up to its highest level $\left(\mathrm{VC}_{10}\right)$ in both soils. Except available $\mathrm{P}$, all the nutrient contents were much higher in non-calcareous soil compared to acid soil.

Table 5b. Effects of different levels of vermicompost on the fertility of post harvest soils

\begin{tabular}{|c|c|c|c|c|c|c|c|c|c|c|}
\hline \multirow{2}{*}{$\begin{array}{l}\text { Levels of } \\
\text { VC }\end{array}$} & \multicolumn{2}{|c|}{$\begin{array}{c}\text { Available S } \\
\left(\mu \mathrm{g} \mathrm{g}^{-1}\right)\end{array}$} & \multicolumn{2}{|c|}{$\begin{array}{c}\text { Exch. Ca } \\
\left(\mathrm{cmol} \mathrm{kg}^{-1}\right)\end{array}$} & \multicolumn{2}{|c|}{$\begin{array}{l}\text { Exch. Mg } \\
\left(\mathrm{cmol} \mathrm{kg}^{-1}\right)\end{array}$} & \multicolumn{2}{|c|}{$\begin{array}{l}\text { Available Zn } \\
\quad\left(\mu g^{-1}\right)\end{array}$} & \multicolumn{2}{|c|}{$\begin{array}{c}\text { Available B } \\
\left(\mu \mathrm{g} \mathrm{g}^{-1}\right)\end{array}$} \\
\hline & AS & NS & AS & NS & AS & NS & AS & NS & AS & NS \\
\hline $\mathrm{VC}_{0}$ & $13.06 \mathrm{~d}$ & $13.00 d$ & $0.15 b$ & $2.10 d$ & $0.60 \mathrm{~b}$ & $1.20 \mathrm{c}$ & $1.30 \mathrm{~b}$ & $0.80 c$ & $0.33 c$ & $0.23 c$ \\
\hline $\mathrm{VC}_{5}$ & $16.35 c$ & $17.62 \mathrm{c}$ & $1.80 \mathrm{a}$ & $5.36 c$ & $0.85 a$ & $3.73 b$ & 1.75ab & $0.92 c$ & $0.49 b$ & $0.30 \mathrm{bc}$ \\
\hline $\mathrm{VC}_{7.5}$ & $20.25 b$ & $24.76 b$ & $2.18 a$ & $7.55 b$ & $0.99 a$ & $5.90 a$ & $1.93 a$ & $1.10 \mathrm{~b}$ & $0.80 a$ & $0.47 \mathrm{~b}$ \\
\hline$V_{10}$ & $22.16 a$ & $29.79 a$ & $2.50 \mathrm{a}$ & $10.67 a$ & $1.15 \mathrm{a}$ & $6.25 a$ & $2.07 a$ & $1.29 a$ & $0.90 a$ & $0.58 a$ \\
\hline $\mathrm{CV}(\%)$ & 4.53 & 10.38 & 10.61 & 4.12 & 5.20 & 9.30 & 9.30 & 3.40 & 9.40 & 7.40 \\
\hline $\mathrm{LSD}_{0.05}$ & 1.95 & 3.13 & 0.90 & 0.81 & 0.85 & 0.51 & 0.24 & 0.12 & 0.11 & 0.08 \\
\hline
\end{tabular}

AS = Acid soil, NS = Non-calcareous soil, CV = Coefficient of variance, LSD = Least significant difference, Exch.= Exchangeable

The highest values of the parameters were obtained when vermicompost was applied @ $10 \mathrm{th} \mathrm{h}^{-1}$ and the lowest from the initial soil $\left(\mathrm{VC}_{0}\right)$. Orozco et al. (1996) described that vermicompost contains nutrients such as phosphorus, potassium, and magnesium as available to plants. Manivannan et al. (2009) has reported that an earthworm-processed waste material contains a higher concentration of exchangeable $\mathrm{K}$ due to enhanced microbial activity during the vermicomposting process, which consequently enhances the rate of mineralization.

\section{Conclusion}

The results revealed that growth and yield attributes such as plant height, branch and leaf number, leaf area and dry weight of leaves were significantly influenced by different levels of VC. All plant parameters were increased with the advancement of growth period (60 DAP) and increased rate of $\mathrm{VC}$ up to $7.5 \mathrm{t} \mathrm{ha}^{-1}$ and then declined with further additions. The leaf biomass yield increased by $335 \%$ and $338 \%$ in acid and in non-calcareous soil, respectively over control. The overall performance of non-calcareous soil was superior to acid soil in terms of both plant and soil parameters studied. The acidity of both soils significantly decreased with the increased application of VC ranging from 4.9 to 5.7 in acid soil and 6.5 to 7.2 in non-calcareous soil. Total N, available P, 
exchangeable $\mathrm{K}, \mathrm{Ca}, \mathrm{Mg}$, available $\mathrm{S}, \mathrm{Zn}, \mathrm{B}$ were also significantly increased with the increased levels of VC up to its highest level (VC @ 10t ha ${ }^{-1}$ ) in both soils. Thus the results suggest that VC @ $7.5 \mathrm{t} \mathrm{ha} \mathrm{h}^{-1} \mathrm{might}^{\mathrm{b}}$ be applied for getting maximum leaf biomass yield of stevia and $10 \mathrm{t} \mathrm{ha}^{-1}$ for increasing the fertility of both soils.

\section{Acknowledgement}

This research work was supported by Bangladesh Agricultural Research Council (BARC), Farmgate Dhaka.

\section{References}

Arancon, N.Q. and Edwards, C.A., 2006. Effects of vermicomposts on plant growth. In: Proceedings of the Vermi-Technologies Symposium for Developing Countries, Department of Science and Technology-Phillippine Council for Aquatic and Marine Research and Development, Los Banos, Philippines.

Atiyeh, R.M., Lee, S., Edwards, C.A., Arancon, N.Q. and Metzger, J.D. 2002. The influence of humic acids derived from earthwormprocessed organic wastes on plant growth. Biores. Technol. 84: 7-14.

Azarpour, E., Moraditochaee, M. and Bozorgi, H.R. 2013. Effects of vermicompost application under methanol foliar spraying on dry leaf yield and biomass yield of Stevia rebaudiana (bert.) in north of Iran. ARPN J. Agri. Bio. Sci.. 8(5): 419-422.

Barathi, N. 2003. Stevia- The calorie free natural sweetener. Natural Product Radiance 2 : 120-122.

Dominguez, J., Edwards, C.A. and Subler, S. 1997. A comparison of composting and vermicomposting. Biocycle. 4: 57-59.

Edwards, C.A. 1995. Historical overview of vermicomposting. BioCycle.: 56-58.

Geuns, J.M. 2004. The safety of stevioside. Laboratory of Functional Biology. KUL euven, Euprint ed., Parkbosstraat 3.3001. Heverlee, Belgium. pp. 85-127.

Gomez, K.A. and Gomez, A.A. 1984. Statistical Procedure for Agricultural Research. $2^{\text {nd }}$ edn. International Rice Research Institute. Los Banos, Philippines. pp. 207-215.

Hasan, H.M. 2008. Agronomic management practice for the improvement of growth and yield of stevia (Stevia rebaudiana Bert.). MS Thesis. Dept. Agron., BAU., Mymensingh.

Kale, R.D.1998. Earthworm Cinderella of organic farming. Prism Book Pvt Ltd. Bangalore, India.p. 88

Khan, M.A.R. 2014. Production technology of stevia (Stevia rebaudiana) by stem cutting. PhD Thesis, Department of Agronomy, Bangladesh Agricultural University, Mymensingh.

Khanom, S. 2007. Growth, leaf yield and nutrient uptake by stevia as influenced by organic and chemical fertilizers grown on various types of soil. MS Thesis, Department of Agricultural Chemistry, Bangladesh Agricultural University, Mymensingh.

Kumar, M.E., Charan, Gaval, Rajesh, A., Rathod, Pradeep and Chandregowda, M. 2011. Effect of organic manures and biofertilizers on growth and yield of stevia (Stevia rebaudiana). J. Ecobio., 29(2): 81-88.

Manivannan,S., Balamurugan, M., Parthasarathi, K., Gunasekaran, G. and Ranganat, L.S. 2009. Effect of vermicompost on soil fertility and crop productivity - beans (Phaseolus vulgaris). J. Env. Bio,. 30(2): 275-281

Nasrin, D. 2008. Effect of nitrogen on the growth, yield and nutrient uptake by stevia. MS Thesis, Department of Agricultural Chemistry, Bangladesh Agricultural University, Mymensingh.

Page, A.L., Miller, R.H. and Keeney, D.R. (eds). 1982. Method of Soil Analysis, Part-2 Chemical and Microbiological Properties, $2^{\text {nd }}$ edn., American Society of Agronomy, Inc. Madison, Wisconsin, USA.

Rashid, Z., Rashid, M., Inamullah, S., Rasool, S. and Bahar, F.A. 2013. Effect of different levels of farmyard manure and nitrogen on the yield and nitrogen uptake by stevia (Stevia rebaudiana Bertoni). African J. Agri. Res., 8: 3941-3945.

Sahni, S., Sarma, B.K., Singh, D.P., Singh, H.B. and Singh, K.P. 2008. Vermicompost enhances performance of plant growthpromoting rhizobacteria in Cicer arietinum rhizosphere against Sclerotium rolfsii and quality of strawberry (Fragaria $\mathrm{x}$ ananassaDuch.). Crop Protec. 27: 369-376.

Sunrider 2007. Stevia health benefits.Sunrider. Newsletter (http://www.diana2.com/f/Stevia_Sunrider.pdf).

Wort, S.J. 2013. Stevia leaf(Stevia rebaudiana). The Tillotson Institute of natural health.

Zaman, M.M., Chowdhury, M.A.H. and Chowdhury, T. 2015. Growth parameters and leaf biomass yield of stevia (Stevia rebaudiana, Bertoni) as influenced by different soil types of Bangladesh. J. Bangladesh Agril. Univ. 13(1): 33-40. 